\title{
Women's Attitudes Towards Negotiating Safe Sexual Practices in Nigeria: Do Family Structure and Decision-making Autonomy Play a Role?
}

Chukwuechefulam Kingsley Imo ( $\square$ imochuksco@yahoo.com )

Adekunle Ajasin University https://orcid.org/0000-0002-4201-8431

Clifford 0. Odimegwu

University of the Witwatersrand

Nicole De Wet-Billings

University of the Witwatersrand

Research article

Keywords: Family structure, decision-making, attitudes, safe, sexual practices, Nigeria

Posted Date: September 21st, 2020

DOI: https://doi.org/10.21203/rs.3.rs-63036/v1

License: (c) (i) This work is licensed under a Creative Commons Attribution 4.0 International License.

Read Full License

Version of Record: A version of this preprint was published at BMC Women's Health on January 22nd, 2022. See the published version at https://doi.org/10.1186/s12905-022-01602-7. 


\section{Abstract}

\section{Background}

The risk of contracting sexually transmitted infections (STIs) is related to women's sexual attitudes, beliefs, and power dynamics within marriages in developing countries. Despite the interventions towards improving women's sexual health and well-being, the risk of transmission of STIs which disproportionately affect women continues to be widespread in most sub-Saharan African countries including Nigeria. The dearth of social research on the influence of family structure and decision-making autonomy on women's attitudes towards negotiating safe sexual practices necessitated this study in Nigeria.

\section{Methods}

The study involved analyses of data from nationally representative and weighted sample size of 28,219 ever-married or cohabiting women aged 15-49 years from the 2018 Nigeria Demographic and Health Survey. Descriptive and analytical analyses were carried out, including frequency tables, Pearson's chisquare test, and multivariate binary logistic regression model.

\section{Results}

The overall prevalence of having strong attitudes towards negotiating safe sexual practices were $76.7 \%$ and $69.6 \%$ for a wife justified in asking the husband to use a condom if he has an STI and refusing to have sex with the husband if he had sex with other women, respectively. The analyses further showed that polygamous unions negatively influenced urban and rural women's attitudes towards negotiating safe sexual practices with partners, for instance, the belief that a wife is justified asking the husband to use a condom if he has STI (aOR: 0.71; Cl: 0.61-0.83 and aOR: 0.74; Cl: 0.67-0.81, respectively). Similarly, urban and rural women whose husbands/partners made independent decisions on their healthcare were less likely to belief that a wife is justified in asking the husband to use a condom if he has STI (aOR: 0.60; Cl: 0.47-0.76 and aOR: 0.80; Cl: 0.67-0.97, respectively). Plausibly, women's decision-making autonomy on issues relating to their earnings and healthcare might have constrained them to compromise their sexual relationships with partners.

\section{Conclusion}

The outcomes of this study have some policy implications for both maternal and child health. Hence, the need to intensify programmes aimed at improving women's sexual health and rights towards achieving sustainable development goals of preventing deaths of newborns, ending STIs and creating gender in Nigeria.

\section{Background}


In the context of global health priorities, sexually transmitted infections (STIs), including human immunodeficiency virus (HIV)/acquired immunodeficiency syndrome (AIDs) remain reproductive and public health concerns. The STIs, particularly HIV/AIDS, disproportionately affect women, compared to their male counterparts [1], and the risk of contracting the infections is related to sexual attitudes, beliefs, and power dynamics that exist among sex partners $[2,3]$. Consequently, a woman's level of negotiating safe sexual practice concerning the time and conditions of sex with a partner could predict her ability to control a variety of reproductive health outcome and manage the consequences, especially in marriage.

Marriage is a social union that influences spousal communication on sexual and reproductive health activities. It has been shown that sexual relationships are important in marriages; hence, denying partner sex is discouraged, while unprotected sexual intercourse is perceived in many cultures as strengthening the marriage institution [4]. Emerging studies have shown that partners' communication is associated with the use of modern contraceptives [5], and women's power and autonomy is favourably related to better sexual and reproductive health, including use of contraceptives [6]. Because of the patriarchal society present in many Sub-Saharan African countries, men's perceptions regarding contraceptives are the primary influences over couples' sexual practices $[7,8]$. As a result of the competition to win husband's love due to the presence of other women in the family, women may find it difficult to raise their voices to men regarding sexual matters [9]. Safer sex dialogue in polygamous relationships is regarded as appropriate only between the husband and the younger wife since the younger wife is perceived at risk of engaging in extramarital relations [10]. Again, women in polygamous unions tend not contraceptive methods because having many children is reportedly a powerful strategy to get more leverage over their co-wives and their husbands, even if they do not wish to have more children [11].

The foremost of interventions that are geared towards improving sexual health and well-being in developing countries is the efforts to increase safe sexual practices which include negotiating sexual activity with one's partner. Consequently, unsafe sexual practices are those which increase the chances of contracting STIs and experiencing unintended pregnancies [12]. This accounts for the identification of modern contraceptives uptake as a measurable indicator of universal access to sexual and reproductive health care in sustainable development goals [13].

Cultural and institutional norms like gender-based power inequalities within sexual relationships negatively affect women's sexual and reproductive health [14-16]. Key among these is the reason for engaging in unsafe sexual activities in marriage [17]. Cultural norms and values that place married women subordinate to men which give them unlimited sexual rights over their wives [18]. Previous studies have shown a widespread social conviction that African women in marital or sexual unions abide by their partners' decisions and wishes to ensure stability in relationships [19-20]. Also, fear of being neglected by one's husband and losing him to other women accounted for the compromise of women's positions in issues of reproduction [21]. This is especially the situation in developing countries with patriarchal norms where gender-based status disadvantages perpetuate women's vulnerability to the contraction of STIs [22-24] and contributes to the decisions men make concerning their partners' sexual practices [25]. In most marriages, efforts to avoid unsafe sex by women may be construed by men as an 
infringement on their conjugal rights [26]. The unequal power over sex is also displayed by men's unwillingness to practice safe sex [27] and demands in that regard by women are often portrayed as a sign of mistrust or infidelity [28]. Most women engage in risky sexual practices with partners to show love and view such behaviour as an important means of increasing their connectedness with their partners [29-31], and because they remain dependent on their partners which prevents them from adopting safer sex measures [32].

Socio-economic factors influence women's positions in sexual and reproductive issues. It has been reported that the ability of married or cohabiting women to refuse sex with partners is positively associated with their education [33]. Education provides women with the knowledge and helps them to adopt attitudes and behaviours that enable them to revoke cultural norms and values that promote inequality in marriage [34]. Meanwhile, another study revealed that women with higher education are more likely to engage in unsafe sexual practices and was attributed to higher incomes that could afford unsafe lifestyles [35]. Also, the economic independence of women increases their power in marital and sexual decisions and protects them from engaging in unsafe sexual practices and exposure to STIs [3637]. Other similar studies have established the influence of people's unemployment status on their sexual practices, especially when the most disadvantaged people become unemployed [38]. Also, studies have shown that place of residence [39-41], as well as ethnic concentration [42-43], influence sexual and reproductive behaviours. Also, becoming older among couples increases their chances of becoming HIV positive [44].

The fact that most families are male-headed significantly influences the attitudes of women in communications related to sexual practices. Studies have shown that men's negative attitudes on safe sexual practices in Nigeria have been reported, as some men believe that approving partners' contraceptive use could make women promiscuous [45-46]. On the other hand, male's involvement in sexual and reproductive health have been found to increase the uptake contraceptive methods by improving spousal communication through pathways of increased knowledge or decreased male opposition [47-48]. Conventionally, public health has focused on adverse outcomes of sexual practices. Regarding the importance of spousal communication on decision-making about sexual and reproductive health, women's sexual practices increase their susceptibility to STIs [49]. Hence, the STIs, particularly HIV/AIDs, disproportionately affect women compared with their male counterparts [50].

In the context of global health priority, several countries including Nigeria have made various strategies to implement international resolution through policies, laws, and legislation by making sexual coercion against women socially and culturally unacceptable. Though, studies have revealed the influence of socio-demographic, marital and psychological factors, gender norms, and women's position within the household as well as community factors on women's ability to negotiate sex in many parts of the globe has been examined [35,51-53]. Other studies considered condom use and sexual negotiation among young men and women [54]; women's household decision-making autonomy and safer sex negotiation [55]; women's decision-making about self-protection during sexual activity [56]; household decisionmaking among married women [57] and women's reproductive health decision-making [58]. Despite the 
governmental and non-governmental efforts to minimize new infections in most countries with generalized or high burden epidemics, including Nigeria, the comparison and measurement of the interaction influence of family structure and decision-making autonomy on attitudes towards negotiating safe sexual practices has been quite limited. This is evident in Nigeria where HIV menace has remained prevalent as the second-largest HIV epidemic in the world [59].

Consequently, women are disproportionally affected by HIV accounting for about $56 \%$ of adults living with HIV in Nigeria, as well as the percentage of HIV-exposed infants tested for HIV before eight weeks of age standing at $18 \%$ in 2018 [1]. No doubt, this might account for the largest burden of babies born with HIV in the world - one in every four babies [60]. Consequently, one of the major factors that contribute to the spread of STIs in a developing country like Nigeria is the ability to negotiate for safe sexual practices among women. The high levels of HIV transmission through sexual intercourse make negotiating for safe sex indispensable, especially in marital unions where women's status is compromised by societal expectations, thereby increasing their vulnerability to STIs transmission. Despite the report that over twothird of married women $69.7 \%$ and $77.3 \%$ belief that a wife is justified in refusing to have sex with the husband if he had sex with other women and asking her husband to use a condom if he has an STI, respectively, modern contraceptive use among currently married women is $12 \%$ and $17 \%$ for any method [61]. This might account for about $56 \%$ of adults living with HIV in Nigeria, as well as the percentage of HIV-exposed infants tested for HIV before eight weeks of age standing at $18 \%$ in 2018 [1].

Therefore, women-based approach with respect to attitudes towards negotiating safe sexual practices provides a novel opportunity to understand the processes related to STIs in marriage [62-63], with emphasis on the theory of reasoned action establishing that beliefs, attitudes, intentions and behaviours form a causal chain [64]. Thus, this study filled the identified gaps by investigating the interaction effect of family structure and decision-making autonomy on women's attitudes towards negotiating safe sexual practices in Nigeria, especially among women who are married or living with partners. Information about intra-familial factors including family structure and decision-making autonomy influencing women's negotiating power for safe sexual practices is essential to the design and assessment of interventions to improve sexual health, as well as achieve sustainable development in Nigeria.

\section{Methods}

\section{Data source and design}

The data for this study were obtained from the individual recode data file of the 2018 Nigeria Demographic and Health Survey (NDHS). The NDHS 2018 is a cross-sectional study and the sixth survey of its kind to be implemented by the National Population Commission (NPC). Although the 2006 Population and Housing Census of the Federal Republic of Nigeria (NPHC) conducted by NPC did not provide the number of households and population for each Enumeration Area (EA), population estimates were published for 774 Local Government Areas (LGAs). A combination of information from cartographic material demarcating each EA and the LGA population estimates from the census was used to identify 
the list of EAs, estimate the number of households, and distinguish EAs as urban or rural for the survey sample frame. The survey provides up-to-date information on demographic and health indicators in Nigeria. The sample was selected using a stratified, two-stage cluster design, with enumeration areas (EAs) as the sampling units for the first stage. The second stage was a complete listing of households carried out in each of the 1,400 selected EAs. A representative sample of 41,668 households was selected for the survey. Data were generated from 41,821 women age 15-49 and 13,311 men aged 15-59. A detailed report of the data collection methods and procedures for 2018 NDHS has been published elsewhere [61]. The analyses for this study covered a weighted sample of 28,219 women (urban - 10,171 and rural -18,048) who reported being either married or living with the partners during the survey. This is to improve the representativeness of the data from the group of women interviewed in the survey (i.e. 2013-2018).

\section{Variables measurements}

\section{Outcome variables}

The outcome variables for this study were two basic attitudinal questions on women's negotiating safe sexual practices: These questions are (i) wife justified asking that they use a condom if she knows that her husband has an STI which has two categories of "yes=1" and "no=0", and (ii) wife justified refusing to have sex with the husband if he had sex with other women has two categories of "yes=1" and "no=0". The respondents whose responses were in affirmative were classified as having 'strong' attitudes towards negotiating safe sexual practices - coded as 1 , otherwise classified as having 'weak' - coded as 0 .

\section{Explanatory variables}

The main explanatory variables in this study were family structure and decision-making autonomy of the following four subjects: 1 ) the number of other wives, 2) the person who usually decides on respondent's health care, 3) the person who usually decides on large household purchases, and 4) the person who usually decides how to spend respondent's earnings. Hence, possible answers were respondent alone, respondent and husband/partner jointly, husband/partner alone, someone else and other. The categories were collapsed into three including alone, jointly and by combining the last three categories into one (husband/partner alone and others). Respondents who reported making independent decisions (alone) on the decision-making subjects represents 'decision-making autonomy'. The co-variables included in the analysis were age, marital status, educational attainment, employment status, wealth quintile and region. To make interpretation simpler and more meaningful, some variables were regrouped from their original categories in the datasets. For instance, age: 15-24/25-34/35+ years; educational attainment: no education/ primary/secondary or tertiary; and wealth quintile: lowest/middle/highest. The selection of the independent variables was informed by their documented significant association with sexual practices and other related aspects of life in the literature and their availability in the dataset.

\section{Statistical analysis}


The dataset was carefully checked for missing values and weighted before the analysis. Three levels of analysis (univariate, bivariate and multivariate) were employed in this study. Pearson chi-square test was used at the bivariate level to investigate urban-rural disparity of attitudes towards negotiating safe sexual practices for all the explanatory variables. At the multivariate level, binary logistic regression analysis was used to measure the odds ratios (OR) of the association between women's attitudes towards negotiating safe sexual practices and the explanatory variables. Five tables were used to explain the results. Table 3 presented the unadjusted odds ratio (OR) showing the association between women's attitudes towards negotiating safe sexual practices and all the explanatory variables. Table 4 considered the adjusted odds ratio (aOR) of the influence of family structure and decision-making characteristics on outcome variables. Finally, Table 5 presented the adjusted odds ratio (aOR) of the association between women's attitudes towards negotiating safe sexual practices and all the main explanatory variables, as well as selected covariables. Measures of association between the outcome variable and explanatory variables were expressed as OR with $95 \%$ confidence intervals $(\mathrm{Cl})$. A variable with $\mathrm{OR}$ greater than 1.00 implied that the variable increases the likelihood of the outcome (attitudes towards negotiating safe sexual practices), while it is the opposite when the OR is less than 1.00. All the analyses were conducted using Stata software (version 14). Svy command in Stata was used to adjust for the complex survey design of the DHS data.

\section{Ethical consideration}

This study utilized secondary datasets with all identifier information removed. Hence, confidentiality and anonymity are guaranteed. The formal approval to use the data was obtained from the DHS programme.

\section{Results}

\section{Characteristics of respondents}

Description of respondents by selected background characteristics is presented in Table 1 with weighted frequencies and percentages. Overall, the mean age of the women was 32 years, while urban and rural women were 33 and 31 years, respectively. There were slightly older rural women in the sample than their urban counterparts ( $43.9 \%$ vs. $37.2 \%)$. With respect to educational attainment, the largest proportion of women had no formal education, with a huge variation by place of residence. For instance, $56.7 \%$ of the rural women had no formal education relative to $61.8 \%$ of their urban counterparts with secondary/tertiary education. Over two-thirds of the women reported to be currently working $(70.1 \%)$, but slightly higher among urban women (75.7\%) compared with $67 \%$ of women residing in rural areas. Generally, the largest proportion of women was found in the lowest wealth quintile households, with variation across the place of residence. The majority of urban women $(67.1 \%)$ were found in the highest wealth index households, compared to $61.0 \%$ of rural women in the lowest wealth index households. Considering region of residence, the proportions of the women ranged from $28.5 \%$ in the North-west and $10.0 \%$ in the South-south with variations across the place of residence.

\section{Family structure, decision-making measures and negotiating safe sexual practices}


Table 2 presents the results of family structure, decision-making and negotiating safe sexual practices of respondents. The results indicate that about $70 \%$ of the women were found in monogamous unions, with slightly more rural women than their urban counterparts in polygamous unions $(34.8 \%$ and $21.7 \%$, respectively). Concerning decision-making measures, Table 2 shows that frequency of having autonomy in healthcare decision and the large household purchase was low, but lower among rural women compared with women residing in urban areas. On the other hand, women had a notably higher rate of autonomy in making decisions on how to spend their earnings (69.5\%). A similar result was observed among urban and rural women with a slight difference $(67.7 \%$ and $70.9 \%$, respectively). Considering attitudes towards negotiating safe sexual practices, over two-thirds of the women believe that a wife is justified asking the husband to use a condom if he has STI and refusing to have sex with the husband if he had sex with other women.

\section{Bivariate association of women's attitudes towards negotiating safe sexual practices with all the explanatory variables}

Wife justified asking the husband to use a condom if he has STI. The results of unadjusted associations between a wife justified asking husband to use a condom if he has STI and all the explanatory variables using multivariate analysis presented in Table 3 showed significant relationships between decisionmaking measures and wife justified asking the husband to use a condom if he has STI. For instance, coming from polygamous unions was significantly found not to be a protective factor for believing that a wife is justified asking the husband to use a condom if he has STI among urban and rural women (OR: $0.71 ; \mathrm{Cl}: 0.63-0.80$ and OR: $0.82 ; \mathrm{Cl}: 0.76-0.87$, respectively). Our results further revealed that the odds of believing that a wife is justified asking the husband to use a condom if he has STI significantly reduced among urban women who made joint decisions on their healthcare with husbands/partners (OR: 0.67; $\mathrm{Cl}$ : 0.55-0.80) compared with women who had decision-making autonomy on their healthcare. Similar results were observed among urban and rural women whose husbands/partners made such decisions independently (OR: $0.43 ; \mathrm{Cl}: 0.36-0.52$ and OR: $0.68 ; \mathrm{Cl}: 0.59-0.77$, respectively). Women in urban and rural areas who had less autonomy in deciding large household purchases were significantly less likely to believe that a wife is justified asking the husband to use a condom if he has STI. For instance, urban and rural women whose husbands/partners made independent decisions on large household purchase (OR: $0.60 ; \mathrm{Cl}: 0.48-0.74$ and OR: $0.59 ; \mathrm{Cl}: 0.50-0.71$, respectively) had lower odds of believing that a wife is justified asking the husband to use a condom if he has STI. Also, the odds significantly reduced for urban and rural women who had less autonomy in deciding how to spend their earnings (OR: 0.36; $\mathrm{Cl}$ : 0.30-0.45 and OR: 0.28 ; Cl: 0.24-0.32, respectively), compared with those in the reference category.

The results in Table 3 further revealed that all the co-variables were significantly associated with women's belief that a wife is justified asking the husband to use a condom if he has STI, except women's age.

Concerning educational attainment, the odds of believing that a wife is justified by asking the husband to use a condom if he has STI, significantly increased for both urban and rural women with an increase in educational attainment. Being employed significantly increase the odds of believing that a wife is justified asking the husband to use a condom if he has STI for both urban and rural women (OR: 1.46; Cl: 
1.30-1.63 and OR: 1.29; Cl: 1.20-1.38, respectively). Also, the likelihood of women of believing that a wife is justified asking the husband to use a condom if he has STI significantly increased wealth quintile of both urban and rural women. For instance, urban and rural women found in highest wealth quintile households (OR: 1.94; $\mathrm{Cl}: 1.69-2.23$ and OR: 1.71 ; Cl: 1.56-1.88, respectively) were significantly more likely to believe that a wife is justified asking the husband to use a condom if he has STI. In comparison with women in the North-central, our results showed that the likelihood of believing that a wife is justified asking the husband to use a condom if he has STI significantly increased among urban women found in the Southern regions and rural women found in the North-east, North-west and South-east (OR: 1.20; Cl: 1.09-1.32; OR: 1.13; Cl: 1.03-1.24 and OR: 2.99; Cl: 2.47-3.61, respectively).

Refusing to have sex with the husband if he had sex with other women: The unadjusted multivariate analysis association results between women's attitudes towards refusing to have sex with the husband if he had sex with other women are presented in Table 3. Our results showed that both urban and rural women found in polygamous unions (OR: 0.73 ; Cl: 0.66-0.81 and OR: $0.86 ; \mathrm{Cl}$ : 0.80-0.91, respectively) significantly had lower odds of believing that a woman is justified in refusing to have sex with the husband if he had sex with other women. Surprisingly, the results further revealed that rural women having autonomy in deciding their healthcare and large household purchase significantly were less likely to believe that a woman is justified in refusing to have sex with the husband if he had sex with other women. On the other hand, women having less decision-making autonomy on how to spend their earnings reduced the odds of believing that a woman is justified in refusing to have sex with the husband if he had sex with other women. For instance, urban and rural women whose husbands/partners made independent decisions on how to spend their earnings (OR: 0.70; Cl: 0.57-0.85 and OR: 0.41; Cl: 0.36-0.46, respectively) significantly had lower odds, compared with those in the reference category.

Table 3 further revealed that the likelihood of believing that a woman is justified in refusing to have sex with the husband if he had sex with other women significantly reduced among older women in rural areas, relative to those aged 15-24. An increase in educational attainment increased women's odds of believing that a woman is justified in refusing to have sex with the husband if he had sex with other women. For instance, urban and rural women with secondary/tertiary education were 30\% (OR: 1.51; Cl: 1.36-1.68) and $6 \%$ (OR: $1.20 ; \mathrm{Cl}: 1.12-1.30)$, respectively more likely than those with primary education to believe that a woman is justified in refusing to have sex with the husband if he had sex with other women. Also, urban and rural women found in highest wealth quintile households (OR: 1.21; Cl: 1.07-1.37 and OR: $1.09 ; \mathrm{Cl}: 1.00-1.18$, respectively) were significantly more likely to believe that a woman is justified in refusing to have sex with the husband if he had sex with other women. A similar result was observed among urban women found in middle wealth quintile households (OR: 1.31; Cl: 1.12-1.52). Regarding the region of residence, our results showed that the likelihood of believing that a woman is justified in refusing to have sex with the husband if he had sex with other women increased among urban and rural women found in the North-east, North-west, South-east, South-south and South-west, compared with those in the reference category. 


\section{Multivariate association of women's attitudes towards negotiating safe sexual practices with family structure and decision-making measures}

Wife justified asking the husband to use a condom if he has STI: The results of adjusted associations between wife justified asking the husband to use a condom if he has STI and decision-making measures using multivariate analysis are presented in Table 4. Our results showed that urban and rural women found in polygamous unions (aOR: $0.71 ; \mathrm{Cl}: 0.61-0.83$ and aOR: $0.74 ; \mathrm{Cl}: 0.67-0.81$, respectively) were less likely to believe that a wife is justified in asking the husband to use a condom if he has STI, compared with those in monogamous unions. Similar results were observed for urban and rural women who had less autonomy in deciding on their healthcare. For instance, the odds of believing that a wife is justified in asking the husband to use a condom if he has STI significantly reduced for urban and rural women whose husbands/partners made independent decisions on their healthcare (aOR: 0.60; Cl: 0.47-0.76 and aOR: 0.80; Cl: 0.67-0.97, respectively). Also, urban and rural women whose husbands/partners made independent decisions on how to spend their earnings (aOR: 0.38; Cl: 0.31-0.47 and aOR: 0.28; Cl: 0.240.31 , respectively) significantly had lower odds of believing that a wife is justified in asking the husband to use a condom if he has STI, relative to those with decision-making autonomy.

Refusing to have sex with the husband if he had sex with other women: The results of adjusted multivariate analysis association between women's attitudes towards refusing to have sex with the husband if he had sex with other women are presented in Table 4. Urban and rural women found in polygamous unions (aOR: 0.65 ; $\mathrm{Cl}$ : $0.57-0.74$ and aOR: $0.75 ; \mathrm{Cl}: 0.68-0.82$, respectively) were less likely to have the belief that a woman is justified in refusing to have sex with the husband if he had sex with other women than those in monogamous unions. Surprisingly, our results further revealed that both urban and rural women who had less autonomy in deciding their healthcare (aOR: 1.24; $\mathrm{Cl}$ : 1.03-1.24 and aOR: 2.12; Cl: 1.81-2.49, respectively) significantly had higher odds of believing that a woman is justified in refusing to have sex with the husband if he had sex with other women, relative to those in the reference category. Our results further showed that urban and rural women whose husbands/partners made independent decisions on how to spend their earnings (aOR: 0.70; $\mathrm{Cl}$ : 0.57-0.85 and aOR: $0.41 ; \mathrm{Cl}: 0.36-0.46$, respectively) were significantly less likely to believe that a woman is justified in refusing to have sex with the husband if he had sex with other women, compared with those who had decision-making autonomy.

\section{Multivariate association of women's attitudes towards negotiating safe sexual practices with family structure, decision-making measures and selected co-variables}

Wife justified in asking the husband to use a condom if he has STI: The results of adjusted associations between a wife being justified in asking the husband to use a condom if he has an STI and decisionmaking measures, as well as co-variables using multivariate analysis, are presented in Table 5. Our results showed that the likelihood of believing that a wife is justified in asking the husband to use a condom if he has STI reduced among women found in polygamous unions, though the result was significant among rural women (OR: $0.81 ; \mathrm{Cl}: 0.73-0.90)$. Also, women who had less autonomy in deciding on their healthcare and how to spend their earnings had lower odds of believing that a wife is justified in 
asking the husband to use a condom if he has an STI. For instance, the odds of believing that a wife is justified in asking the husband to use a condom if he has an STI significantly reduced for urban and rural women whose husbands/partners made independent their healthcare (OR: 0.59; Cl: 0.46-0.76 and OR: 0.83; Cl: 0.68-1.00, respectively). Also, women who made joint decisions and whose husbands/partners made independent decisions on how to spend their earnings were less likely to believe that a wife is justified in asking the husband to use a condom if he has STI.

The results in Table 5 further revealed that the odds of believing that a wife is justified in asking the husband to use a condom if he has an STI, significantly increased with additional educational attainment for both urban and rural women. For employment status, being employed was significantly found not to be a protective factor for believing that a wife is justified in asking the husband to use a condom if he has an STI among urban and rural women (OR: 0.49; Cl: 0.30-0.79 and OR: 0.08; Cl: 0.53-0.84, respectively). Our results showed that an increase in wealth quintiles of both urban and rural women increased the likelihood to believe that a wife is justified in asking the husband to use a condom if he has an STI. For instance, urban and rural women found in the highest wealth quintile households (OR: 1.24; Cl: 1.01-1.52 and OR: $1.74 ; \mathrm{Cl}: 1.49-2.03$, respectively) significantly had lower odds of believing that a wife is justified in asking the husband to use a condom if he has an STI, compared with those in the reference category. Considering region of residence, the results showed that the likelihood of believing that a wife is justified in asking the husband to use a condom if he has an STI significantly increased among urban and rural women found in the North-east (OR: 1.94; Cl: 1.42-2.64 and OR: 1.77; Cl: 1.49-2.09, respectively) and South-east (OR: 1.40; Cl: 1.10-1.78 and OR: 1.42; Cl: 1.11-1.82, respectively), but significantly reduced among urban and rural women found in South-west (OR: 0.66; Cl: 0.54-0.81 and OR: 0.62; Cl: 0.51-0.75, respectively). Besides, the likelihood of believing that a wife is justified in asking the husband to use a condom if he has an STI significantly increased among rural women found in the North-west (OR: 1.26; Cl: 1.08-1.47), but reduced for those found in South-south (OR: 0.63; Cl: 0.53-0.76).

Refusing to have sex with the husband if he had sex with other women: The results of adjusted multivariate analysis association between women's attitudes towards refusing to have sex with the husband if he had sex with other women as presented in Table 5, showed that urban and rural women found in polygamous unions (OR: $0.63 ; \mathrm{Cl}: 0.55-0.79$ and $\mathrm{OR}: 0.73 ; \mathrm{Cl}: 0.66-0.81$, respectively) were less likely to believe that a woman is justified in refusing to have sex with the husband if he had sex with other women, compared with their counterparts in the reference category. The likelihood of believing that a woman is justified in refusing to have sex with the husband if he had sex with other women increased among women with less decision-making autonomy on their healthcare. Though, the result was significant among rural women. Our results further showed that urban and rural women whose husbands/partners made independent decisions on large household purchase (OR: 0.71; Cl: 0.57-0.87 and OR: 0.40 ; Cl: $0.35-0.46$, respectively) were significantly less likely to believe that a woman is justified in refusing to have sex with the husband if he had sex with other women, compared with those in the reference category. 
Concerning educational attainment, an increase in urban and rural women's educational attainment increased the odds of believing that a woman is justified in refusing to have sex with the husband if he had sex with other women. Being employed significantly reduced the odds of believing that a woman is justified in refusing to have sex with the husband if he had sex with other women among urban and rural women (OR: 0.85; $\mathrm{Cl}$ : 0.62-1.17 and OR: 0.56; Cl: 0.45-0.71, respectively). Rural women found in highest wealth quintile households (OR: $1.21 ; \mathrm{Cl}: 1.07-1.37)$ were significantly more likely to believe that a woman is justified in refusing to have sex with the husband if he had sex with other women, compared with those in the lowest wealth quintile households. Our results on the region of residence showed that the likelihood of believing that a woman is justified in refusing to have sex with the husband if he had sex with other women increased among urban and rural women found in the North-east, North-west and South-west regions, relative to those from North-central.

\section{Discussion}

The objective of this paper was to investigate the interaction influence of family structure and decisionmaking autonomy on women's attitudes towards negotiating safe sexual practices in Nigeria. Our study revealed that a large proportion of both urban and rural women believed that a wife is justified in asking the husband to use a condom if he has an STI and refusing to have sex with the husband if he had sex with other women. Most of the women were found in monogamous unions, though higher in urban areas compared to rural areas. The disparity by place of residence could be attributable to the burden of raising large families in urban areas. Also, most women lacked decision-making autonomy on their healthcare and large household purchase, while women autonomy was strongly exhibited on how to spend their earnings. It emerged from our study that differences in family structure brought about variations in believing that a wife is justified in asking the husband to use a condom if he has an STI and refusing to have sex with the husband if he had sex with other women. For instance, coming from polygamous unions was perceived not to be a protective factor for negotiation for safer sexual practices compared to their counterparts in monogamous unions in most marriages. The plausible explanation for this observation could be attributed to the existence of competition among wives to win the husband's affection and attention in polygamous unions as a result of the presence of other women in the family. As a result, most women might be constrained not to raise their voices to men on issues relating to sexual practices $[9,20]$. Hence, the findings of this study have some policy implications because the presence of a younger wife is perceived to a threat to older wives exposing and compelling women to the risk of engaging in unsafe sexual relations [10].

Further, it was revealed that women who had less autonomy in deciding on their healthcare and how to spend their earnings were less likely to believe that a wife is justified in asking the husband to use a condom if he has an STI. This explains the reflection of how women's opportunity to make decisions that affect their lives influence a range of sexual practices and relationship power [52]. The study suggests that women having decision-making autonomy for their healthcare and how to spend their earnings might be constrained to compromise their positions in sexual relationships with partners to show strong love in the unions. Our study further established that giving women the autonomy to decide on their 
healthcare could discourage them from making healthy and proper decisions on sexual matters in most marriages. Additionally, the culture of male dominance and women subordination to men encourages African women in marital or sexual unions to abide by their partners' decisions to ensure stability in relationships [19-20]. The fact that women who had decision-making autonomy on their healthcare were less likely to believe that a woman is justified in refusing to have sex with the husband if he had sex with other women could be attributed to the avoidance of being portrayed as a sign of mistrust or infidelity [28].

After incorporating all the explanatory variables (Table 5), our study showed significant direct relationships between women's educational attainment and attitudes towards negotiating safe sexual practices among women in urban and rural areas. This corroborates previous studies in the observation that education influences people's ability to adopt attitudes and behaviours that enable them to revoke cultural norms and values that promote inequality in marriage $[34,65]$. For employment status, the fact that women who reported to employed were less likely to believe that a wife is justified in asking the husband to use a condom if he has an STI and refusing to have sex with the husband if he had sex with other women, could explain the negative influence of women's exposure, as well as a swap of ideas in the workplaces on issues relating to negotiating safe sexual practices. Expectedly, our study established that coming from households with more wealth quintile increased women's attitudes towards negotiating safe sexual practices in marriage. Consequently, earning more income by women provides them with some leverage in initiating safe sexual practices. Hence, the need to encourage and introduce more women education and empowerment programmes geared towards promoting safe sexual practices in marriage.

Our study established some substantial regional variations in negotiating safe sexual practices among women in Nigeria. The plausible explanation for these variations could be attributable to the differences in cultural practices relating to sexual relationships in marriage across the regions. Although women from the South-south and South-west regions were less likely to believe that a wife is justified in asking the husband to use a condom if he has an STI, the results of our study call for urgent policy attention to reduce the spread of STIs and burden of babies born with HIV in the country. Besides, the regional variations in attitudes towards negotiating safe sexual practices indicate the plausible influence of region-level factors including differences of social norms and values relating to sexual relationships. This suggests the need for further studies that will explore intra-familial influences (decision-making autonomy) at the regional level, as well as intensify region-based programmes aimed at ensuring the achievement of Sustainable Development Goals (SDGs) 3 target of ending STIs including HIV and AIDs increasing maternal mortality ratio and burden of babies born with infections from STIs in Nigeria.

\section{Limitations}

This study, however, is not without some limitations. One of the limitations is in using DHS data that constrained inference of cause-effect relationship given that the data are cross-sectional. The family structure and three measures of women's decision-making autonomy associated with attitudes towards negotiating safe sexual practices are relatively temporary. Hence, there is the likelihood of reporting 
bias/discordance regarding the type of family structure and the level of decision-making autonomy as the participants/respondents were women and, since it is to a large extent a subjective phenomenon. However, the survey lacked information on behavioural and cultural factors that might have influenced the estimation of the influence of family structure and decision-making autonomy on attitudes towards negotiating safe sexual practices. Also, the influence of family structure and decision-making autonomy on attitudes towards negotiating safe sexual practices might be under/over-estimated when only women's reports are considered independently. Despite these limitations, the findings are important for more strategic policies and programmes, especially for disadvantaged women concerning family structure and decision-making participation influencing negotiating safe sexual practices in Nigeria.

\section{Conclusion}

This study significantly showed that family structure and lack of decision-making autonomy negatively impact a women's ability to protect themselves from STIs. Polygamous unions were perceived not to be a protective factor for negotiation for safer sexual practices in most marriages plausibly because of the existence of competition among wives to win the husband's affection and attention. The fact that women who had less autonomy in deciding on their healthcare and how to spend their earnings were less likely to believe that a wife is justified asking the husband to use a condom if he has STI, explains the reflection of how women's opportunity to make decisions that affect their lives influence a range of sexual practices and relationship power. Hence, women with decision-making autonomy on their healthcare and how to spend their earnings might be constrained to compromise their positions in sexual relationships with partners to show strong love in the unions. The women's weak attitudes towards refusing to have sex with husband if he has sex with other women by those had decision-making autonomy on their healthcare could be attributed to the avoidance of being portrayed as a sign of mistrust or infidelity by partners.

Given the protective factors of women's socioeconomic status to having strong attitudes towards believing that a wife is justified asking the husband to use a condom if he has STI and refusing to have sex with husband if he has sex with other women has some policy implications. There is the need for the creation of supportive environments in which such attitudes are transformed into behaviour with consideration of region-level factors including cultural and social norms differences which have grave implications for vulnerability to STI in marriages. There should be more studies that will explore contextual influences, as well as intensify programmes aimed at improving women's sexual health, especially disadvantaged geographic regions in a patriarchal society where most women lack decisionmaking autonomy on their sexual health.

\section{Policy implications}

The findings of this study on the influence of family structure and decision-making autonomy on women's attitudes towards negotiating safe sexual practices, using the latest NDHS have several policy implications for STIs' prevention in the future among ever-married or cohabiting women in Nigeria. Both 
government and non-government organisations should look beyond the existing health care programmes to intensify efforts of spreading the reach of pooled resources and income-generating projects that are geared towards empowering women to gain a higher ground/voice in negotiating safe sexual practices in marital unions. No doubt, adopting the implications of these findings are essential for futuristic strategies towards STIs' prevention by empowering women, especially the disadvantaged to air their voices in family structure and intra-familial decision-making processes as STIs disproportionately affect women in Nigeria. Additionally, adopting the findings of this study would enable policy-makers to develop more strategies towards achieving the SDGs' targets of preventing deaths of newborns, ending STIs, and creating gender parity in Nigeria. There should be further research in the sub-field as well as on larger study area.

\section{Abbreviations}

AIDS: Acquired Immunodeficiency Virus; aOR: Adjusted Odds Ratio; Cl: Confidence Intervals; DHS: Demographic and Health Survey; EAs: Enumeration Areas; HIV: Human Immunodeficiency Virus; Individual Recode: IR; LGAs: Local Government Areas; NDHS: Nigeria Demographic and Health Survey; NPC: National Population Commission; NPHC: Nigeria Population and Housing Census; OR: Unadjusted Odds Ratio; RC: Reference category; SDGs: Sustainable Development Goals; STIs: Sexually Transmitted Infections; UNAIDS: The Joint United Nations Programme on HIV and AIDS; WHO: World Health Organisation

\section{Declarations}

\section{Ethics approval and consent to participant}

This study utilized NDHS 2018 individual recode (IR) dataset with all personally identifiable information removed. Hence, confidentiality and anonymity are guaranteed. Therefore, no further ethics approval was required. However, permission to download and use the data was obtained from Measure DHS/ICF International, USA.

\section{Consent for publication}

Not applicable

\section{Availability of data and materials}

The NDHS 2018 individual recode (IR) dataset was used for this study and is freely available from the DHS Program archive at https://www.dhsprogram.com/data/dataset.

\section{Competing interests}

The authors declare that they have no competing interests. 


\section{Funding}

Not applicable.

\section{Authors' contributions}

ICK: Conceptualization and design of the study; accessed and used the dataset, literature review, statistical analysis and interpretation, drafting the manuscript, revision for intellectual input. COO and NDW participated in the revision for important intellectual input. All authors read and approved the final manuscript.

\section{Acknowledgements}

The authors are grateful to the ICF International for making Demographic and Health Survey datasets publicly available that made this study possible.

\section{Authors' information}

CKI is a lecturer in the Department of Sociology, Adekunle Ajasin University, Ondo State, Nigeria and was a Postdoctoral fellow in the Demography and Population Studies (DPS) programme at the University of the Witwatersrand, Johannesburg, South Africa; and COO is a Professor of the DPS programme at the University of the Witwatersrand, Johannesburg, South Africa. NDW is an Associate Professor of the DPS programme at the University of the Witwatersrand, Johannesburg, South Africa.

\section{References}

1. The Joint United Nations Programmes on HIV/AIDS. Data Sheet. UNAIDS 2018.

2. Pulerwitz J, Gortmaker SL, DeJong W. Measuring sexual relationship power in HIV/STD research. Sex Roles. 2000; 42(7/8),637-60.

3. Oyediran KA, Odutolu O, Atobatele AO. Intergenerational Sexual Relationship in Nigeria: Implications for Negotiating Safe Sexual Practices, Social and Psychological Aspects of HIV/AIDS and their Ramifications, Gobopamang Letamo (Ed.), 2011.

4. Ali MM, Cleland J, Shah IH. Condom use within marriage: a neglected HIV intervention. B World HealthOrgan. 2004;82(3),180-8

5. Rahman M, Islam A, Islam M. Rural-urban differentials of knowledge and practice of contraception in Bangladesh. Popul. Soc. Stud. 2010;18(2), 87-110.

6. Rahman M. Women's autonomy and unintended pregnancy among currently pregnant women in Bangladesh. Child Health J. 2012;16(6),1206-14.

7. Nwachukwu I, Obasi 00. Use of modern birth control methods among rural communities in Imo State, Nigeria. Afr J Reprod Health. 2008;12(1), 101-8. 
8. Omideyi AK, Akinyemi Al, Aina Ol, Adeyemi AB, Fadeyibi OA, Bamiwuye SO, et al. Contraceptive practice, unwanted pregnancies and induced abortion in Southwest Nigeria. Glob. Public Health. 2011;6(Suppl 1), 52-72.

9. Philip AA, Simona BA, Shelley C, James M. Spousal communication about the risk of contracting HIV/AIDS in rural Malawi: what do spouses know about each other? AIDS 2010;14(1),103-112.

10. Sally MM, Eveline G, Marcel T, Sonja M, Constanze P. It is not expected for married couples': A qualitative study on challenges to safer sex communication among polygamous and monogamous partners in South-eastern Tanzania, Glob. Health Action. 2016;9(1), 323-326.

11. Rossi P. Strategic choices in polygamous households: theory and evidence from Senegal. Econ. Stud. 2019;86(3), 1332-1370

12. Chialepeh WN, Susuman AS. Risk factors of inconsistent condom use among sexually active youths: Implications for human immunodeficiency virus and sexual risk behaviours in Malawi. Asian Afr. Stud. 2017;52(4), 484-496.

13. Choi Y, Fabic MS, Hounton S, Koroma D. Meeting demand for family planning within a generation: prospects and implications at country level. Glob. Health Action. 2015; 8, 29734. http://dx.doi.org/10.3402/gha.v8.29734

14. Browne FA, Wechsberg WM, Bowling JM, Luseno WK. Correlates of male condom use skills among high risk women in South Africa. J. Sex Res. 2012; 49(2-3), 255-263.

15. Hatcher AM, Colvin CJ, Ndlovud N, Dworkin SL. Intimate partner violence among rural South African men: alcohol use, sexual decision-making, and partner communication. Cult HealthSex. 2014; 16(9):1023-1039.

16. McMahon JM, Volpe EM, Klostermann K, Trabold N, Xue Y. A systematic review of the psychometric properties of the sexual relationship power scale in HIV/AIDS research. Sex. Behav. 2015; 44(2), 267294.

17. Wusu O, Isiugo-Abanihe UC. Understanding sexual negotiation between married partners: A study of the Ogu families in South Western Nigeria. Popul. Stud. 2010; 23(2), 151-171.

18. Scott S. HIV/AIDS: Understanding socio-cultural factors and their influence on sexual behaviour and decision making in Africa. Journal of the University of Manitoba Anthropology Student Association. 2010; 28, 83-93.

19. Eliason S, Baiden F, Quansah-Asare G, Graham-Hayfron Y, Bonsu D, Phillips J, et al. Factors influencing the intention of women in rural Ghana to adopt postpartum family planning. Health. 2013;10(1), 10-34.

20. Palamuleni ME. Socio-economic and demographic factors affecting contraceptive use in Malawi. Afr J Reprod Health. 2013;17(3), 91-104.

21. Imo CK, Isiugo-Abanihe UC, Chikezie DC. Perception of childbearing women on gender roles in reproductive decision making and under-five children health status in Abia State, Nigeria. Gender and Behaviour. 2016; 14(1), 7040-7056. 
22. Pettifor AE, Diana MM, Helen VR, Nancy SP. Sexual power and HIV risk, South Africa. Emerg Infect Dis. 2004; 10(11), 1996-2004.

23. Reniers G. Marital strategies for regulating exposure to HIV. Demography 2008;45(2), 417-438.

24. Bingenheimer JB. Men's multiple sexual partnerships in 15 sub-Saharan African countries: Sociodemographic patterns and implications. Fam. Plan. 2010; 41(1), 1-17. https://doi.org/10.1111/j.1728-4465.2010.00220.x

25. Macia M, Pranitha M, Ashley G. Masculinity and Male Sexual Behaviour in Mozambique. Cult HealthSex. 2011;13(10), 1181-1192.

26. Adamczyk A, Greif M. Education and risky sex in Africa: unravelling the link between women's education and reproductive health behaviours in Kenya. Sci. Res. 2011; 40(2011), 654-666.

27. Falola T, Heaton MM. HIV illness and African wellbeing. Rochester: University Rochester Press. University of Rochester Press; 1st edition, 2007.

28. Ayiga N. Rates and predictors of consistent condom use by people living with HIV/AIDS on antiretroviral treatment in Uganda. J HealthPopul Nutr. 2012; 30(3), 270-280.

29. Miller CL, Bangsberg DR, Tuller DM, Senkungu J, Kawuma A, Frongillo EA, et al. Food security and sexual risk in an HIV endemic community in Uganda. AIDS 2011; 15(7), 1512-1819.

30. Shannon K, Leiter K, Phladze N, Hlanza Z, Tsai C, Heisler M, et al. Gender inequality norms are associated with increased male perpetrated rape and sexual risks for HIV infection in Botswana and Swaziland. PLoS One. 2012;7, e28739.https://doi.org/10.1371/journal.pone.0028739

31. Jones D, Bagga R, Nehra R, Sethi S, Walia K, Kumar M, et al. Reducing sexual risk behaviour among high risk couples in Northern India. J. Behav. Med. 2013; 20(3), 344-354.

32. Dodoo FNA, Frost AE. Gender in African population research: the fertility/reproductive health example. Rev. Sociol. 2008; 34(1), 431-452.

33. Feyisetan B, Oyediran K. Can married or cohabiting women negotiate for safer sex? Findings from Recent Demographic and Health Survey of Two West African Countries. Paper presented at the annual meeting of the Population Association of America, Denver, Colorado, April 26-28, 2018.

34. Kroska A, Elman C. Change in attitudes about employed mothers: exposure, interests and gender ideology discrepancies. Sci. Res. 2009;38(2), 366-382.

35. Tenkorang EY, Maticka-Tyandale E, Rajulton F. A multi-level analysis of risk perception, poverty and sexual risk taking among young people in Cape Town, South Africa. Health Place. 2011; 17(2), 525535.

36. Osuafor GN, Mturi AJ. Attitudes towards sexual control within conjugal union in the era of the HIV/AIDS epidemic in Mafikeng, South Africa. Popul. Stud. 2014; 28(1), 538-550.

37. Haberland NA. The case for addressing gender and power in sexuality and HIV education: A comprehensive review of evaluation studies. Guttmacker Institute. 2015; 4(3), 311-351.

38. Hammer T. Labour market integration of unemployed youth from a life course perspective: the case of Norway. J. Soc. Welf. 2007; 16(3), 249-257. 
39. Audu BM, El-Nafaty AU, Bako BG, Melah GS, Mairiga AG, Kullima AA. Attitude of Nigerian women to contraceptive use by men. J Obstet Gynaecol. 2008; 28(6), 621-625.

40. Teye JK. Modern contraceptive use among women in the Asuogyaman district of Ghana: is reliability more important than health concerns? Afr J Reprod Health. 2013; 17(2), 58-71.

41. Marrone G, Abdul-Rahman L, De Coninck Z, Johansson A. Predictors of contraceptive use among female adolescents in Ghana. Afr J Reprod Health. 2014; 18(1), 102-109.

42. Mberu BU, White MJ. Internal migration and health: premarital sexual initiation in Nigeria. Soc. Sci. Med. 2011;72(8), 1284-1293.

43. Carlson DL, McNulty TL, Bellair PE, Watts S. Neighbourhoods and racial/ethnic disparities in adolescent sexual risk behaviour. Youth Adolesc. 2014; 43(9), 1536-1549.

44. Wyrod R. Masculinity and the persistence of AIDS stigma. Cult Health Sex. 2011;13(14), 443-456.

45. Okwor EU, Olaseha IO. Married men's perception about spousal use of modern contraceptives: a qualitative study in Ibadan northwest local government area, southwest Nigeria. Int Q Community Health Educ. 2010; 30(3), 223-238.

46. Akinso 0 , Akinso $S$. Factors that influence male involvement in family planning: a qualitative study of men of reproductive age in Ibadan North-east and North-west, Oyo State. Contraception. 2015; 92(4), 395-414.

47. Sternberg P, Hubley J. Evaluating men's involvement as a strategy in sexual and reproductive health program. Health Int. 2004; 19(3), 389-396.

48. Hartmann M, Gilles K, Shattuck D, Kerner B, Guest G. Changes in couple's communication as a result of a male-involvement in family planning intervention. Health Commun. 2012; 17(7), 802-819.

49. Islam MS, Alam MS, Hasan MM. Inter-spousal communication on family planning and its effect on contraceptive use and method choice in Bangladesh. Asian Soc. Sci. 2014; 102(2), 189-201.

50. Adebayo SB, Olukolade RI, Idogho O, Anyanti J, Ankomah A. Marital status and HIV prevalence in Nigeria: Implications for effective prevention programmes for women. Adv Infect Dis. 2013; 3(3), 210218.

51. Ung M, Boateng GO, Armah FA, Amoyaw JA, Luginaah I, Kuuire V. Negotiation for safer sex among married women in Cambodia: The role of women's autonomy. Biosoc. Sci. 2014;46(1), 90-106.

52. Jesmin SS, Cready C. Can she refuse sex when her husband has a sexually transmitted infection? Attitudes toward married women's safe sex negotiation in Bangladesh. Cult HealthSex. 2014; 16(6), 666-682.

53. Yujiro S, Alice PS, Siera V, Roger A, Isaac L. Women's household decision-making autonomy and safer sex negotiation in Nigeria: An analysis of the Nigeria Demographic and Health Survey. AIDS Care. 2017;30(2), 240-245.

54. Kalysha C, Janan JD, Nathan JL, Busiwe N, Alexis P, Zishan C, et al. Sexual self-efficacy and gender: A review of condom use and sexual negotiation among young men and women in sub-Saharan Africa. Sex Res. 2018; 55(4-5), 522-539. 
55. Sano Y, Sedziafa AP, Vercillo S, Antabe R, Luginaah I. Women's household decision-making autonomy and safer sex negotiation in Nigeria: An analysis of the Nigeria Demographic and Health Survey. AIDS Care. 2018; 30(2), 240-245.

56. Konkle-Parker D, Fouquier K, Portz K, Wheeless L, Arnold T, Harris C, et al. Women's decision-making about self-protection during sexual activity in the deep south of the USA: a grounded theory study. Cult Health Sex. 2017; 20(1), 84-98.

57. Musalia J. Household Decision Making Among Married Women in Kenya: A Latent Class Analysis. Sex Roles. 2018; 78, 182-193.

58. Darteh EKM, Dickson KS, Doku DT. Women's reproductive health decision-making: A multi-country analysis of demographic and health surveys in sub-Saharan Africa. PLoS One. 2019;14(1), e0209985. https://doi.org/10.1371/pone.0209985

59. National Agency for the Control of AIDS. National Strategic Framework on HIV and AIDS: 2017-2021. NACA, 2017.

60. Central Intelligence Agency. The World factbook, CIA, 2018.

61. National Population Commission (NPC) \& ICF International. Nigeria Demographic and Health Survey 2018. Abuja, Nigeria, and Rockville, Maryland, USA: NPC and ICF 2019.

62. Burton J, Darbes LA, Operario D. Couples-focused behavioural interventions for prevention of HIV: Systematic review of the state of evidence. AIDS Behav. 2010; 14. doi: 10.1007/s10461-008-9471-4.

63. Karney BR, Hops H, Redding CA, Reis HT, Rothman AJ, Simpson JA. A Framework for Incorporating Dyads in Models of HIV-Prevention. AIDS Behav. 2010; 14(Suppl 2), 189-203.

64. Fishbein M, Ajzen I. Belief, attitude, intention and behaviour: An Introduction to Theory and Research, Reading, MA: Addison-Wesley, 1975.

65. Oreopoulos P, Salvanes KG. Priceless: the non-pecuniary benefits of schooling. J Econ Perspect. $2011 ; 25(1), 159-184$.

\section{Tables}

Table 1: Percentage distribution of respondents' selected background characteristics 


\begin{tabular}{|c|c|c|c|}
\hline Characteristics & Urban \& Rural & Urban & Rural \\
\hline & $\mathrm{N}(\%)$ & $\mathrm{N}(\%)$ & $\mathrm{N}(\%)$ \\
\hline Mean & 32 years & 33 years & 31 years \\
\hline $15-24$ & $5,990(21.2)$ & $1,468(14.4)$ & $4,522(25.1)$ \\
\hline $25-34$ & $11,039(39.1)$ & $4,234(41.6)$ & 6,805(37.7) \\
\hline 35 and above & $11,190(39.7)$ & $4,469(43.9)$ & $6,721(37.2)$ \\
\hline \multicolumn{4}{|c|}{ Educational attainment } \\
\hline No education & $12,427(44.0)$ & $2,196(21.6)$ & $10,231(56.7)$ \\
\hline Primary & $4,669(16.6)$ & $1,686(16.6)$ & $2,983(16.5)$ \\
\hline Secondary/tertiary & $11,123(39.4)$ & $6,289(61.8)$ & $4,834(26.8)$ \\
\hline \multicolumn{4}{|l|}{ Employment status } \\
\hline Not working & $8,425(29.9)$ & $2,470(24.3)$ & $5,955(33.0)$ \\
\hline Currently working & $19,794(70.1)$ & 7,701(75.7) & $12,093(67.0)$ \\
\hline \multicolumn{4}{|l|}{ Wealth quintile } \\
\hline Lowest & $12,348(43.8)$ & $1,340(13.2)$ & $11,008(61.0)$ \\
\hline Middle & $5,714(20.2)$ & 1,999(19.7) & $3,715(20.6)$ \\
\hline Highest & $10,157(36.0)$ & $6,832(67.1)$ & $3,325(18.4)$ \\
\hline \multicolumn{4}{|l|}{ Region } \\
\hline North-central & $5,153(18.3)$ & $1,604(15.8)$ & $3,549(19.7)$ \\
\hline North-east & $5,492(19.5)$ & $1,121(11.0)$ & $4,371(24.2)$ \\
\hline North-west & $8,049(28.5)$ & $1,977(19.4)$ & 6,072(33.6) \\
\hline South-east & $3,141(11.1)$ & 1,994(19.6) & $1,147(6.4)$ \\
\hline South-south & $2,813(10.0)$ & $948(9.3)$ & $1,865(10.3)$ \\
\hline South-west & $3,571(12.6)$ & $2,527(24.9)$ & $1.044(5.8)$ \\
\hline
\end{tabular}

Table 2: Distribution of respondents' family structure, decision-making measures and negotiating safe sexual practices 
Characteristics

$\begin{array}{lll}\begin{array}{l}\text { Urban \& } \\ \text { Rural }\end{array} & \text { Urban } & \text { Rural } \\ \mathrm{N}(\%) & \mathrm{N}(\%) & \mathrm{N}(\%)\end{array}$

\section{Family structure}

Monogamous

19,721(69.9) 7,959(78.3) 11,762(65.2)

Polygamous

$8,498(30.1) \quad 2,212(21.7) \quad 6,286(34.8)$

\section{Decision on respondent's health care}

Alone

2,855(10.1) 1,410(13.9) 1,445(8.0)

Jointly

9,554(33.9) 4,419(43.5) 5,135(28.5)

Husband/partner alone and other

15,810(56.0) 4,342(42.6) 11,468(63.5)

Decision on large household purchase

\begin{tabular}{|c|c|c|c|}
\hline Alone & $1,649(5.8)$ & $807(7.9)$ & $842(4.7)$ \\
\hline Jointly & $9,889(35.0)$ & $4,555(44.8)$ & $5,334(29.6)$ \\
\hline Husband/partner alone and other & $16.681(59.2)$ & $4,809(47.3)$ & $11,872(65.8)$ \\
\hline \multicolumn{4}{|c|}{ Decision on how to spend respondent's earning } \\
\hline Alone & $12,009(69.5)$ & $4,940(67.7)$ & $7,069(70.9)$ \\
\hline Jointly & $3,610(20.9)$ & $1,865(25.6)$ & $1,745(17.5)$ \\
\hline Husband/partner alone and other & $1,651(9.56)$ & $493(6.7)$ & $1,158(11.6)$ \\
\hline \multicolumn{4}{|c|}{$\begin{array}{l}\text { Wife justified asking the husband to use a condom if } \\
\text { he has STI }\end{array}$} \\
\hline No & $6,575(23.3)$ & $1,832(18.0)$ & $4,743(26.3)$ \\
\hline Yes & $21,644(76.7)$ & $8,339(82.0)$ & $13,305(73.7)$ \\
\hline \multicolumn{4}{|c|}{$\begin{array}{l}\text { Refusing to have sex with the husband if } \\
\text { he has sex with other women }\end{array}$} \\
\hline No & $8,575(30.4)$ & $2,871(28.2)$ & $5,704(31.6)$ \\
\hline Yes & $19,644(69.6)$ & $7,300(71.8)$ & $12,344(68.4)$ \\
\hline
\end{tabular}

Table 3: Unadjusted bivariate analysis of attitudes towards negotiating safe sexual practices and explanatory variables of respondents 
Characteristics

Characteristics Wife justified asking the husband to
use a condom if he has STI

Urban

OR(95\% Cl)
Rural

$\mathrm{OR}(95 \% \mathrm{Cl})$
Refusing to have sex with husband if he has sex with other women

Urban Rural

OR $(95 \% \mathrm{Cl}) \quad$ OR $(95 \% \mathrm{Cl})$

\section{Family structure}

Monogamous (RC)

1.00

1.00

1.00

1.00

Polygamous

$0.71(0.63-$
$0.80)^{\star \star \star}$

$0.82(0.76-$

$0.73(0.66-$

$0.81)^{\star \star \star}$

$0.86(0.80-$

$0.91)^{\star \star \star}$

\section{Decision on}

respondent's health

care

\begin{tabular}{lllll} 
Alone (RC) & 1.00 & 1.00 & 1.00 & 1.00 \\
\hline Jointly & $0.67(0.55-$ & $0.91(0.79-1.05)$ & $1.05(0.92-1.19)$ & $1.74(1.54-$ \\
& $0.80)^{\star \star \star}$ & & & $1.96)^{\star \star \star}$ \\
$\begin{array}{l}\text { Husband/partner } \\
\text { and other }\end{array}$ & $0.43(0.36-$ & $0.68(0.59-$ & $1.07(0.94-1.22)$ & $1.58(1.42-$ \\
\hline
\end{tabular}

\section{Decision on large household}

\section{Purchase}

\begin{tabular}{|c|c|c|c|c|}
\hline Alone (RC) & 1.00 & 1.00 & 1.00 & 1.00 \\
\hline Jointly & $0.84(0.68-1.05)$ & $0.81(0.67-0.97)^{\star}$ & $1.05(0.89-1.23)$ & $\begin{array}{l}1.51(1.29- \\
1.75)^{\star \star \star}\end{array}$ \\
\hline $\begin{array}{l}\text { Husband/partner } \\
\text { and other }\end{array}$ & $\begin{array}{l}0.60(0.48- \\
0.74)^{\star \star \star}\end{array}$ & $\begin{array}{l}0.59(0.50- \\
0.71)^{\star \star \star}\end{array}$ & $1.08(0.91-1.27)$ & $\begin{array}{l}1.31(1.14- \\
1.51)^{\star \star \star}\end{array}$ \\
\hline
\end{tabular}

\section{Decision on how to spend}

respondent's earning

\begin{tabular}{|c|c|c|c|c|}
\hline Alone (RC) & 1.00 & 1.00 & 1.00 & 1.00 \\
\hline Jointly & $0.89(0.77-1.03)$ & $1.00(0.88-1.14)$ & $0.98(0.87-1.10)$ & $1.03(0.92-1.16)$ \\
\hline $\begin{array}{l}\text { Husband/partner } \\
\text { and other }\end{array}$ & $\begin{array}{l}0.36(0.30- \\
0.45)^{\star \star \star}\end{array}$ & $\begin{array}{l}0.28(0.24- \\
0.32)^{\star \star \star}\end{array}$ & $\begin{array}{l}0.70(0.57- \\
0.85)^{\star \star \star}\end{array}$ & $\begin{array}{l}0.41(0.36- \\
0.46)^{\star \star \star}\end{array}$ \\
\hline
\end{tabular}

\section{Age}

\begin{tabular}{lllll}
$15-24(\mathrm{RC})$ & 1.00 & 1.00 & 1.00 & 1.00 \\
\hline $25-34$ & $1.15(0.99-1.34)$ & $0.99(0.91-1.08)$ & $0.95(0.83-1.09)$ & $\begin{array}{l}0.84(0.77- \\
0.91)^{\star \star \star}\end{array}$ \\
\hline 35 and above & $1.13(0.97-1.31)$ & $1.00(0.92-1.09)$ & $0.95(0.84-1.09)$ & $\begin{array}{l}0.84(0.78- \\
0.92)^{\star \star \star}\end{array}$
\end{tabular}




\section{Education attainment}

\begin{tabular}{|c|c|c|c|c|}
\hline No education (RC) & 1.00 & 1.00 & 1.00 & 1.00 \\
\hline Primary & $\begin{array}{l}1.60(1.38- \\
1.86)^{\star \star \star \star}\end{array}$ & $\begin{array}{l}1.47(1.33- \\
1.61)^{\star \star \star \star}\end{array}$ & 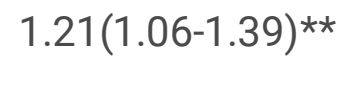 & $1.14(1.04-1.24)^{\star \star}$ \\
\hline Secondary/tertiary & $\begin{array}{l}2.83(2.52- \\
3.19) \star \star \star\end{array}$ & $\begin{array}{l}2.05(1.88- \\
2.23)^{\star \star \star}\end{array}$ & $\begin{array}{l}1.51(1.36- \\
1.68)^{\star \star \star}\end{array}$ & $\begin{array}{l}1.20(1.12- \\
1.30) \star \star \star\end{array}$ \\
\hline \multicolumn{5}{|l|}{ Employment status } \\
\hline Not working (RC) & 1.00 & 1.00 & 1.00 & 1.00 \\
\hline Currently working & $\begin{array}{l}1.46(1.30- \\
1.63)^{\star \star \star}\end{array}$ & $\begin{array}{l}1.29(1.20- \\
1.38)^{\star \star \star}\end{array}$ & $1.05(0.95-1.16)$ & $0.97(0.91-1.04)$ \\
\hline \multicolumn{5}{|l|}{ Wealth Quintile } \\
\hline Lowest (RC) & 1.00 & 1.00 & 1.00 & 1.00 \\
\hline Middle & $\begin{array}{l}1.30(1.10- \\
1.53)^{\star \star}\end{array}$ & $\begin{array}{l}1.34(1.23- \\
1.46)^{\star \star \star}\end{array}$ & $1.31(1.12-1.52)^{\star \star}$ & $0.94(0.87-1.02)$ \\
\hline Highest & $\begin{array}{l}1.94(1.69- \\
2.23) \star \star \star\end{array}$ & $\begin{array}{l}1.71(1.56- \\
1.88)^{\star \star \star}\end{array}$ & $\begin{array}{l}1.21(1.07- \\
1.37)^{\star \star \star}\end{array}$ & $1.09(1.00-1.18)^{\star}$ \\
\hline \multicolumn{5}{|l|}{ Region } \\
\hline North-central (RC) & 1.00 & 1.00 & 1.00 & 1.00 \\
\hline North-east & $0.98(0.82-1.18)$ & $\begin{array}{l}1.20(1.09- \\
1.32)^{\star \star \star}\end{array}$ & $\begin{array}{l}1.88(1.59- \\
2.23)^{\star \star \star}\end{array}$ & $\begin{array}{l}2.17(1.98- \\
2.38)^{\star \star \star}\end{array}$ \\
\hline North-west & $1.13(0.95-1.32)$ & $\begin{array}{l}1.13(1.03- \\
1.24)^{\star \star}\end{array}$ & $\begin{array}{l}2.44(2.10- \\
2.83)^{\star \star \star}\end{array}$ & $\begin{array}{l}2.28(2.09- \\
2.49)^{\star \star \star}\end{array}$ \\
\hline South-east & $\begin{array}{l}1.91(1.59- \\
2.28)^{\star \star \star}\end{array}$ & $\begin{array}{l}2.99(2.47- \\
3.61)^{\star \star \star}\end{array}$ & $\begin{array}{l}1.58(1.38- \\
1.82)^{\star \star \star}\end{array}$ & $\begin{array}{l}2.35(2.03- \\
2.73)^{\star \star \star}\end{array}$ \\
\hline South-south & $\begin{array}{l}1.34(1.09- \\
1.65)^{\star \star}\end{array}$ & $1.10(0.97-1.25)$ & $\begin{array}{l}1.45(1.22- \\
1.72)^{\star \star \star}\end{array}$ & $\begin{array}{l}1.38(1.23- \\
1.54) \star \star \star\end{array}$ \\
\hline South-west & $\begin{array}{l}1.25(1.06- \\
1.46)^{\star \star}\end{array}$ & $1.05(0.90-1.22)$ & $\begin{array}{l}1.52(1.33- \\
1.73)^{\star \star \star}\end{array}$ & $\begin{array}{l}2.04(1.76- \\
2.37)^{\star \star \star \star}\end{array}$ \\
\hline
\end{tabular}

Note: ${ }^{\star} \mathrm{p}<0.05 ;{ }^{*} \mathrm{p}<0.01 ; * \star \star \mathrm{p}<0.001 ; \mathrm{RC}=$ Reference Category

Table 4: Adjusted multivariate analyses of attitudes towards negotiating safe sexual practices and family structure and decision-making characteristics of respondents 


\begin{tabular}{|c|c|c|c|c|}
\hline \multirow[t]{2}{*}{ Characteristics } & \multicolumn{2}{|c|}{$\begin{array}{l}\text { Wife justified asking the husband to } \\
\text { use a condom if he has STI }\end{array}$} & \multicolumn{2}{|c|}{$\begin{array}{l}\text { Refusing to have sex with husband if } \\
\text { he has sex with other women }\end{array}$} \\
\hline & Urban & Rural & Urban & Rural \\
\hline & $\mathrm{aOR}(95 \% \mathrm{Cl})$ & $\mathrm{aOR}(95 \% \mathrm{Cl})$ & $\mathrm{aOR}(95 \% \mathrm{Cl})$ & $\mathrm{aOR}(95 \% \mathrm{Cl})$ \\
\hline \multicolumn{5}{|l|}{ Family structure } \\
\hline Monogamous (RC) & 1.00 & 1.00 & 1.00 & 1.00 \\
\hline Polygamous & $\begin{array}{l}0.71(0.61- \\
0.83)^{\star \star \star}\end{array}$ & $\begin{array}{l}0.74(0.67- \\
0.81)^{\star \star \star \star}\end{array}$ & $\begin{array}{l}0.65(0.57- \\
0.74)^{\star \star \star}\end{array}$ & $\begin{array}{l}0.75(0.68- \\
0.82)^{\star \star \star}\end{array}$ \\
\hline \multicolumn{5}{|l|}{$\begin{array}{l}\text { Decision on } \\
\text { respondent's health } \\
\text { care }\end{array}$} \\
\hline Alone (RC) & 1.00 & 1.00 & 1.00 & 1.00 \\
\hline Jointly & $0.74(0.58-0.94)^{\star}$ & $0.76(0.62-0.94)^{\star}$ & $1.13(0.94-1.36)$ & $\begin{array}{l}1.48(1.24- \\
1.77)^{\star \star \star}\end{array}$ \\
\hline $\begin{array}{l}\text { Husband/partner } \\
\text { and other }\end{array}$ & $\begin{array}{l}0.60(0.47- \\
0.76)^{\star \star \star}\end{array}$ & $0.80(0.67-0.97)^{\star}$ & $\begin{array}{l}1.24(1.03- \\
1.24)^{\star \star \star}\end{array}$ & $\begin{array}{l}2.12(1.81- \\
2.49)^{\star \star \star}\end{array}$ \\
\hline \multicolumn{5}{|c|}{ Decision on large household } \\
\hline \multicolumn{5}{|l|}{ Purchase } \\
\hline Alone (RC) & 1.00 & 1.00 & 1.00 & 1.00 \\
\hline Jointly & $0.93(0.70-1.23)$ & $1.04(0.80-1.35)$ & $0.86(0.70-1.07)$ & $0.98(0.78-1.24)$ \\
\hline $\begin{array}{l}\text { Husband/partner } \\
\text { and other }\end{array}$ & $1.03(0.78-1.36)$ & $1.00(0.79-1.28)$ & $1.10(0.89-1.36)$ & $0.83(0.67-1.03)$ \\
\hline \multicolumn{5}{|c|}{ Decision on how to spend respondent's } \\
\hline \multicolumn{5}{|l|}{ Earning } \\
\hline Alone (RC) & 1.00 & 1.00 & 1.00 & 1.00 \\
\hline Jointly & $0.85(0.72-1.00)$ & $0.95(0.83-1.10)$ & $0.99(0.87-1.13)$ & $1.00(0.88-1.14)$ \\
\hline $\begin{array}{l}\text { Husband/partner } \\
\text { and other }\end{array}$ & $\begin{array}{l}0.38(0.31- \\
0.47)^{\star \star \star}\end{array}$ & $\begin{array}{l}0.28(0.24- \\
0.31)^{\star \star \star}\end{array}$ & $\begin{array}{l}0.61(0.50- \\
0.75)^{\star \star \star}\end{array}$ & $\begin{array}{l}0.36(0.31- \\
0.41)^{\star \star \star}\end{array}$ \\
\hline
\end{tabular}

Note: ${ }^{\star} p<0.05 ; * \star * p<0.001 ; R C=$ Reference Category

Table 5: Adjusted multivariate analyses of attitudes towards negotiating safe sexual practices and explanatory variables of respondents 
Characteristics

Characteristics
Wife justified asking the husband to use a condom if he has STI

Urban

$\operatorname{aOR}(95 \% \mathrm{Cl})$
Rural

$\operatorname{aOR}(95 \% \mathrm{Cl})$
Refusing to have sex with husband if he has sex with other women

Urban Rural

aOR $(95 \% \mathrm{Cl}) \quad$ aOR $(95 \% \mathrm{Cl})$

\section{Family structure}

Monogamous (RC)

1.00

1.00

1.00

1.00

Polygamous

0.89(0.76-1.05)

$0.81(0.73-$
$0.90)^{\star \star \star}$

$0.63(0.55-$

$0.79)^{\star \star \star}$

0.73(0.66-

$0.81)^{\star \star \star}$

\section{Decision on}

respondent's health

care

$\begin{array}{lllll}\text { Alone (RC) } & 1.00 & 1.00 & 1.00 & 1.00 \\ \text { Jointly } & 0.74(0.57-0.95)^{\star} & \begin{array}{l}0.74(0.60- \\ 0.92)^{\star \star}\end{array} & 1.07(0.89-1.29) & 1.38(1.15-1.65)^{\star \star}\end{array}$

Husband/partner

$0.59(0.46-$

$0.76)^{\star \star \star}$

$0.83(0.68-1.00) * \quad 1.08(0.90-1.31)$

$1.88(1.60-$

and other

$2.22)^{\star \star \star}$

\section{Decision on large household purchase}

\begin{tabular}{lllll} 
Alone (RC) & 1.00 & 1.00 & 1.00 & 1.00 \\
\hline Jointly & $0.92(0.69-1.22)$ & $1.07(0.82-1.40)$ & $0.83(0.67-1.03)$ & $0.92(0.73-1.16)$ \\
\hline $\begin{array}{l}\text { Husband/partner } \\
\text { and other }\end{array}$ & $1.12(0.84-1.49)$ & $1.09(0.85-1.40)$ & $1.00(0.81-1.24)$ & $0.77(0.62-0.96)^{\star}$ \\
\hline
\end{tabular}

\section{Decision on how to spend respondent's}

\section{Earning}

\begin{tabular}{|c|c|c|c|c|}
\hline Alone (RC) & 1.00 & 1.00 & 1.00 & 1.00 \\
\hline Jointly & $\begin{array}{l}0.75(0.63- \\
0.89)^{\star \star}\end{array}$ & $0.83(0.72-0.97)^{\star}$ & $1.12(0.98-1.29)$ & $1.04(0.91-1.19)$ \\
\hline $\begin{array}{l}\text { Husband/partner } \\
\text { and other }\end{array}$ & $\begin{array}{l}0.35(0.28- \\
0.44)^{\star \star \star}\end{array}$ & $\begin{array}{l}0.27(0.24- \\
0.32)^{\star \star \star}\end{array}$ & $0.71(0.57-0.87)^{\star \star}$ & $\begin{array}{l}0.40(0.35- \\
0.46)^{\star \star \star}\end{array}$ \\
\hline
\end{tabular}

\section{Education} attainment

\begin{tabular}{lllll} 
No education $(\mathrm{RC})$ & 1.00 & 1.00 & 1.00 & 1.00 \\
Primary & $1.52(1.23-$ & $1.56(1.35-$ & $1.48(1.22-$ & $1.59(1.39-$ \\
& $1.89)^{\star \star \star}$ & $1.79)^{\star \star \star}$ & $1.79)^{\star \star \star}$ & $1.82)^{\star \star \star}$ \\
\hline Secondary/tertiary & $2.49(2.03-$ & $2.18(1.87-$ & $1.68(1.41-$ & $1.62(1.41-$ \\
& $3.05)^{\star \star \star}$ & $2.54)^{\star \star \star}$ & $2.01)^{\star \star \star}$ & $1.86)^{\star \star \star}$
\end{tabular}




\section{Employment status}

$\begin{array}{lllll}\text { Not working (RC) } & 1.00 & 1.00 & 1.00 & 1.00 \\ \text { Currently working } & \begin{array}{l}0.49(0.30- \\ 0.79)^{\star \star}\end{array} & \begin{array}{l}0.08(0.53- \\ 0.84)^{\star \star}\end{array} & 0.85(0.62-1.17) & 0.56(0.45- \\ & & & & 0.71)^{\star \star \star}\end{array}$

\section{Wealth quintile}

\begin{tabular}{lllll} 
Lowest (RC) & 1.00 & 1.00 & 1.00 & 1.00 \\
Middle & $1.06(0.85-1.31)$ & $1.42(1.25-$ & $1.15(0.95-1.40)$ & $1.06(0.94-1.19)$ \\
& & $1.61)^{\star \star \star}$ & & \\
\hline Highest & $1.24(1.01-1.52)^{\star}$ & $1.74(1.49-$ & $0.97(0.81-1.15)$ & $1.24(1.08-1.43)^{\star \star}$ \\
& & $2.03)^{\star \star \star}$ & &
\end{tabular}

\section{Region}

\begin{tabular}{|c|c|c|c|c|}
\hline North-central (RC) & 1.00 & 1.00 & 1.00 & 1.00 \\
\hline North-east & $\begin{array}{l}1.94(1.42- \\
2.64)^{\star \star \star \star}\end{array}$ & $\begin{array}{l}1.77(1.49- \\
2.09)^{\star \star \star}\end{array}$ & $\begin{array}{l}2.35(1.85- \\
2.99) \star \star \star\end{array}$ & $\begin{array}{l}2.59(2.22- \\
3.03)^{\star \star \star \star}\end{array}$ \\
\hline North-west & $1.11(0.87-1.40)$ & $\begin{array}{l}1.26(1.08- \\
1.47)^{\star \star}\end{array}$ & $\begin{array}{l}2.65(2.16- \\
3.25)^{\star \star \star}\end{array}$ & $\begin{array}{l}2.01(1.75- \\
2.32)^{\star \star \star}\end{array}$ \\
\hline South-east & $\begin{array}{l}1.40(1.10- \\
1.78)^{\star \star}\end{array}$ & $\begin{array}{l}1.42(1.11- \\
1.82)^{\star \star}\end{array}$ & $1.11(0.93-1.32)$ & $1.22(1.00-1.48)$ \\
\hline South-south & $0.95(0.72-1.25)$ & $\begin{array}{l}0.63(0.53- \\
0.76)^{\star \star \star}\end{array}$ & $1.12(0.91-1.38)$ & $0.86(0.74-1.01)$ \\
\hline South-west & $\begin{array}{l}0.66(0.54- \\
0.81)^{\star \star \star \star}\end{array}$ & $\begin{array}{l}0.62(0.51- \\
0.75) \star \star \star \star\end{array}$ & $1.30(1.10-1.53)^{\star \star}$ & $\begin{array}{l}1.40(1.16- \\
1.68)^{\star \star \star \star}\end{array}$ \\
\hline
\end{tabular}

Note: ${ }^{\star} \mathrm{p}<0.05 ;{ }^{* \star} \mathrm{p}<0.01 ;{ }^{* \star \star} \mathrm{p}<0.001 ; \mathrm{RC}=$ Reference Category 